\title{
Distribution and Sediment Selection by the Mud Shrimp Upogebia noronhensis (Crustacea: Thalassinidea) and the Potential Effects on the Associated Macroinfaunal Community
}

\author{
Paulo Yukio G. Sumida ${ }^{1, * \mathbb{D}}$, Arthur Z. Güth ${ }^{1}\left(\mathbb{D}\right.$, Cintia Organo Quintana ${ }^{1,2}$ \\ and Ana M. S. Pires-Vanin ${ }^{1}$ \\ 1 Oceanographic Institute, University of São Paulo, Praça do Oceanográfico, \\ São Paulo 191-05508-120, SP, Brazil; azguth@usp.br (A.Z.G.); cintia@biology.sdu.dk (C.O.Q.); \\ amspires@usp.br (A.M.S.P.-V.) \\ 2 Department of Biology, University of Southern Denmark, Campusvej 55, Odense M, 5230 Odense, Denmark \\ * Correspondence: psumida@usp.br; Tel.: +55-11-3091-6543
}

Received: 10 November 2020; Accepted: 16 December 2020; Published: 18 December 2020

\begin{abstract}
Burrowers such as thalassinideans remobilize sediment in benthic ecosystems, altering granulometry, enhancing organic matter cycling and oxygenation. We characterized the distribution of the mud shrimp Upogebia noronhensis and the associated macroinfauna along a depth and granulometric gradient in a shallow subtidal area in the southern Brazilian coast. Mud shrimp densities were estimated by burrow opening count using $0.25 \mathrm{~m}^{2}$ quadrats in three sediment zones: sand, sand-mud transition and mud. Macroinfaunal community descriptors and sediment granulometric characteristics were assessed. U. noronhensis average density varied from 0.6 to 145 individuals $\mathrm{m}^{-2}$ and was highest in the transition zone and lowest in the sand zone. Macrofauna in the sand zone was at least three times more abundant and 1.2 times richer, averaging 436.3 organisms and 39 species, while the transition and mud zones were more even in species distribution (species evenness $>0.7$ ). The shrimp presence seems to be linked to a coarse sand content $<80 \%$ and clay and silt $<40 \%$ in the sediment, a compromise between gallery construction ability and filter-feeding suitability. High densities and aggregated distribution of mud shrimp, combined with alteration of sediment grain composition and organic matter, are likely to affect macroinfaunal abundance nearby the burrows.
\end{abstract}

Keywords: bioturbation; sediment reworking; ecosystem engineer; sublittoral; marine benthos

\section{Introduction}

Large sediment burrowers are normally regarded as ecosystem engineers [1,2] for their key role in transforming and rearranging the seafloor. During these activities, burrowing organisms change the biogeochemical characteristics of the sediment [3,4] in a process called bioturbation [2]. They alter the physical-chemical characteristics of the surrounding sediment and its nutrient exchange with the overlying water column. Bioturbation is defined by the sediment reworking caused by the activity of an animal and the ventilation derived by the water movement for respiration or feeding [2]. Bioturbation leads to a greater availability of dissolved oxygen and organic matter (OM) to deeper sedimentary layers, thus enhancing overall degradation and remineralization rates [5-8].

Burrowing activity may also facilitate the colonization of areas by other species that would not settle in otherwise undisturbed and dysaerobic/anaerobic sediments $[9,10]$. However, burrowers may 
displace enough sediment to hamper or exclude other sympatric species from the burrow surroundings in an interaction known as amensalism [11-13].

Thalassinidean shrimps, commonly known as mud or ghost shrimps, are widely distributed, especially in sand and mud flats and shallow subtidal areas around the world [14-16]. These animals are burrow constructors that constantly tend and maintain their burrows [14,17]. As deposit or filter feeders, thalassinids ingest sediment particles and defecate sediment-laden fecal pellets $[14,18,19]$. They depend on burrows for shelter, feeding and finding a mate; except for a short pelagic larval phase, most thalassinidean species spend their whole life inside them. Thalassinideans are active sediment reworkers and are able to truly transform the habitat around them, conspicuously altering the physical properties and the appearance of the sediment and greatly influencing the community of other benthic organisms and the ecosystem functioning [14,20].

Bottom sediment is a major factor influencing the composition and abundance of benthic communities and is intrinsically related to thalassinidean burrow architecture [21,22]. Laboratory experiments and field studies with Callianassa species indicate that the type of sediment in which burrows are constructed can significantly influence the size of burrows created [21].

The mud shrimp Upogebia noronhensis inhabits sand and mud bottoms along the Brazilian coast from Maranhão State to the south coast of São Paulo State [23,24]. U. noronhensis feeds on small suspended food particles, which are collected by creating a water flux inside the burrow with its ventral appendages [24]. U. noronhensis is a filter feeding mud shrimp, considered an important bioturbator due to their active burrow construction and maintenance. The total length of an adult ranges between 15 and $35 \mathrm{~mm}$; males burrow continuously into the sediment to seek females for mating and gallery linkages with fossorial mating encounters are common [24]. In our study area, reproduction occurs year-round, with increased mating activity during spring and summer [24]. The intense digging activity that is associated with a high population density (ca. 200 individuals $\mathrm{m}^{-2}$ ) [24] makes U. noronhensis a key species for shaping the structure of the local benthic community $[14,25,26]$. The burrow lumen and walls are inhabited by species of bivalves, pinnotherid crabs and gobies [27,28]. In spite of that, the relationship among thalassinidean abundance, sediment grain size and the associated benthic infauna has not been investigated until now in the subtropical western Atlantic.

This study investigates the influence of a granulometric gradient on the distribution and density of $U$. noronhensis. It also tests for the presence of seasaonal changes in these population parameters. Furthermore, it examines the effect of the mud shrimp presence on associated benthic macrofauna, considering particle selection for burrow construction and influence on the organic matter content due to feeding activities. We hypothesize that higher densities of $U$. noronhensis would lead to lower abundance, species richness and diversity of benthic macroinfauna.

\section{Materials and Methods}

The work was conducted in a shallow subtidal area from 6 to $15 \mathrm{~m}$ water depth on the west coast of Anchieta Island (23 $32^{\prime} \mathrm{S}$ and $\left.45^{\circ} 05^{\prime} \mathrm{W}\right)$ in Ubatuba, SE Brazil. Previous work has shown that this area is home to a large population of the thalassinidean shrimp $U$. noronhensis (up to 200 ind. $\mathrm{m}^{-2}$ ), occurring along a depth and sedimentary gradient [24]. The sampled area is located near the rocky granitic shore of Anchieta Island, extending offshore in a gradient as follows: (1) coarse sand, (2) fine sand with silt and clay and (3) silt and clay, hereafter simply referred to as sand, transition and mud zones, respectively (Figure 1). 
a

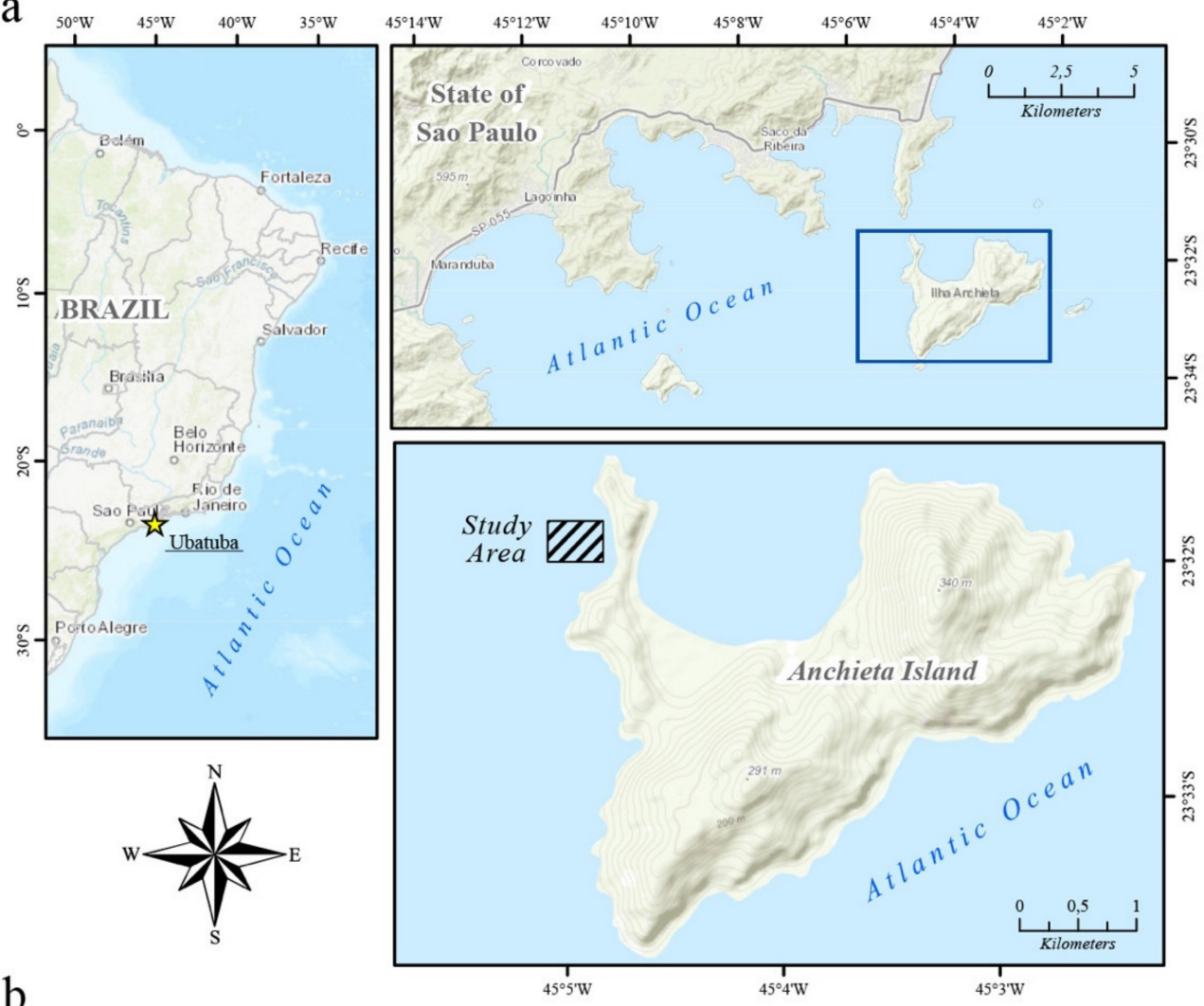

b

Summer and Winter sampling

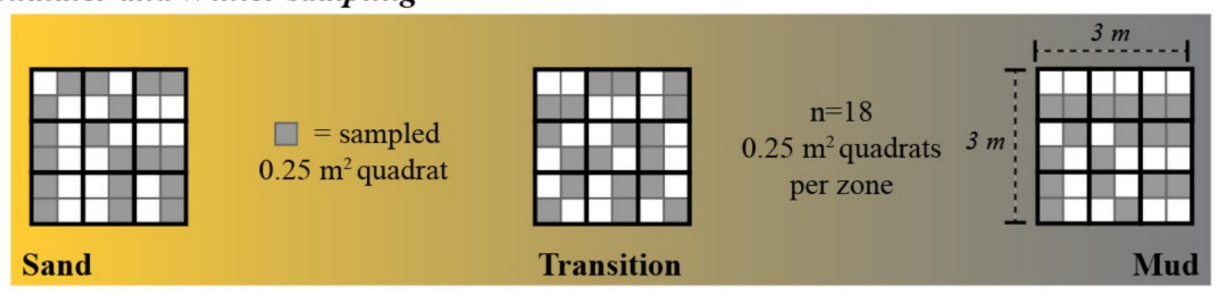

$\vdash$

Autumn sampling

granulometric gradient

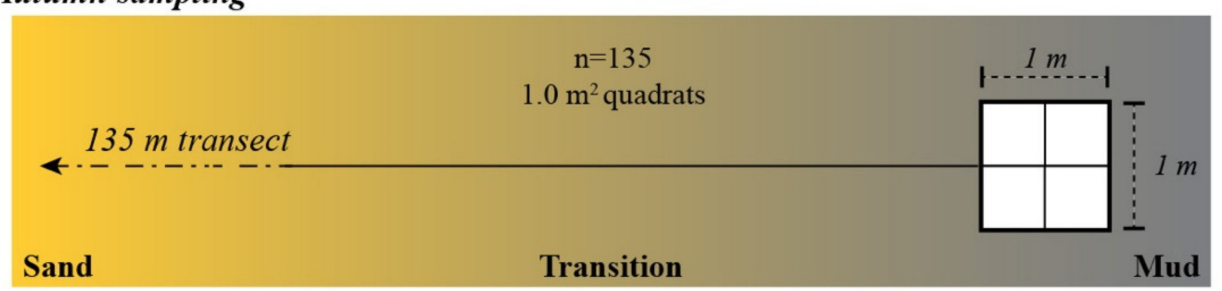

Figure 1. Study area and $U$. noronhensis sampling methods employed at Anchieta island, Ubatuba, Brazil. (a) Map showing the sampled area (hatched rectangle). The sediment gradient goes from mud to sand in an east to west transect. (b) Schematic representation of the sampling methods used to estimate $U$. noronhesis densities through burrow opening counts during summer and winter using a $9 \times 9 \mathrm{~m}$ quadrat for each zone and the autumn sampling method using a $1 \times 1 \mathrm{~m}$ quadrat along a $135 \mathrm{~m}$ transect. Representation not to scale.

Mud shrimp densities and distribution were assessed in a $9 \mathrm{~m}^{2}$ (i.e., $3 \times 3 \mathrm{~m}$ ) area selected within each sediment zone. In this area, we used a $1 \mathrm{~m}^{2}$ quadrat subdivided into four $0.25 \mathrm{~m}^{2}$ squares to facilitate burrow opening counts (Figure 1b). Using scuba diving, $U$. noronhensis burrow openings were counted in only two $0.25 \mathrm{~m}^{2}$ squares, randomly chosen within each $1 \mathrm{~m}^{2}$ frame. Therefore, a total of 18 squares were counted for each sediment zone. To assess potential seasonal changes in $U$. noronhensis 
distribution and density, this approach was performed in the same area during both austral summer (February) and austral winter (July).

The relationship between $U$. noronhensis densities and the co-occurring fauna was only assessed during the collection in the summer. For this, the macroinfauna of the three sediment zones were sampled in triplicates using a $0.1 \mathrm{~m}^{2}$ van Veen grab. The nine resulting samples were then washed with filtered seawater in a $500 \mu \mathrm{m}$ sieve and preserved in $70 \%$ ethanol. Animals were sorted out from the sediment under a dissecting microscope and identified to the lowest possible taxonomic level. Although $U$. noronhensis individuals were occasionally collected by the van Veen grab, this species was excluded from the macrofauna analysis as this collection method is not suitable for sampling mud shrimps [29]. For grain analysis and sediment zone characterization, each van Veen grab sample had subsamples taken from the first $5 \mathrm{~cm}$ layer of sediment.

In a separate sampling event during austral autumn (April), a second assessment of $U$. noronhensis density was made focusing on the effect of the mud shrimp on the grain size and organic matter content in the adjacent sediment. This scuba-based sampling used continuous counting of burrow openings along a $135 \mathrm{~m}$ transect across the sedimentary zone gradient, perpendicular to the coast (i.e., from 6 to $15 \mathrm{~m}$ depth, crossing the three zones) (Figure $1 \mathrm{~b}$ ). For this approach, all burrow openings were counted within a $1 \mathrm{~m}^{2}$ quadrat placed at every meter of the $135 \mathrm{~m}$ transect $(\mathrm{n}=135)$. In addition, ten $20 \times 20 \mathrm{~cm}$ resin castings were made along the transect. Upon removal of the hardened resin casts, sediment samples from the burrow walls attached to the casts were carefully removed and collected. The granulometric characteristics along the transect were described with sediment collection from 33 van Veen grab samples. Sediment samples of the burrow walls were compared with the background adjacent sediment from the van Veen samples.

In the laboratory, the burrow casts were visually examined for any notable differences in burrow architecture in each of the three different zones. Final density of $U$. noronhensis (abundance per meter squared) was corrected using a ratio of 1.8 gallery openings per animal. This ratio was estimated with the data obtained from the resin casts, associating the number of burrow openings with the mud shrimp entrapped in resin, using the method described in Candisani et al. (2001) [24]. The burrow casts were also checked for entrapped commensal organisms.

For grain analysis, 2-3 g wet weight $(\mathrm{ww})$ of the sediment samples were analyzed using sieving and pipetting and graded using the Wentworth scale. Total organic matter (TOM) was estimated by combustion at $500{ }^{\circ} \mathrm{C}$ for $4 \mathrm{~h}$, and calcium carbonate $\left(\mathrm{CaCO}_{3}\right)$ content was estimated by sample acidification [30].

\section{Data Analysis}

The distribution of $U$. noronhensis individuals was calculated within and across sediment types (meters and tens of meters scales, respectively) using the Standardized Morisita Index $\left(I_{p}\right)[31,32]$. This index varies from -1.0 to 1.0, where random distributions give an $I_{p}$ of zero, and positive values denote an aggregated distribution and negative values a uniform distribution [33]. The association between the $U$. noronhensis density assessment methods of direct individual count with resin cast entrapment and of indirect burrow opening count was confirmed with a Pearson's correlation test. We also tested the relationship between $U$. noronhensis density and sediment grain size with a Pearson's correlation test.

For each sediment zone, macroinfaunal communities were defined in terms of species richness (S), abundance (n), Pielou's evenness index $\left(\mathrm{J}^{\prime}\right)$ and Shannon diversity index $\left(\mathrm{H}^{\prime}(\log \mathrm{e})\right)$. The macroinfaunal community composition was also described using multivariate methods [34]. Differences in abundance and species composition between sedimentary zones were tested using a one-way permutational multivariate analysis of variance (PERMANOVA) using Bray-Curtis distances. $p$-values were adjusted using the Monte Carlo approach. The PERMDISP procedure was used to test for homogeneity of dispersion of the data. A similarity percentage analysis (SIMPER) was used to assess the species similarity among samples in the same sedimentary zone and to rank species that contribute the most 
to differences between zones (dissimilarity). A non-metric Multidimensional Scaling (nMDS) plot was used to graphically compare the community similarity among samples and zones. Grain size composition, calcium carbonate and TOM content were related to the zone replicates and to burrow walls and graphically expressed via Principal Coordinates Analysis (PCoA). Each pair relationship was also verified with a Pearson's correlation test. For all of the aforementioned multivariate analyses, we $\log$-transformed $(\log X+1)$ the species abundance data, so the less abundant or rare species were given more weight. The relationship between $U$. noronhensis density and macrofaunal density was tested with a Pearson's correlation test.

Differences in macroinfauna densities and in diversity indexes among sediment zones were tested with a one-way Analysis of Variance (ANOVA). Differences in $U$. noronhensis densities between seasons (summer and winter) and sediment zones (transition and mud zones) were tested with a two-way mixed model ANOVA. In the latter case, we excluded the sand zone from the analysis because of the near absence of burrows in this zone. Pairwise post-hoc tests were performed with Student's $t$-tests or Tukey's test All data was tested for normality and homogeneity of variance and log-transformed $(\log X+1)$ when necessary.

\section{Results}

\subsection{Macroinfaunal Community Analysis}

The sand zone was characterized by the dominance of coarse and medium sand grains (Appendix A, Table A1). Macrofauna from this area (Appendix A, Table A2) were mainly characterized by the presence of the polychaete Exogone arenosa and the gastropod Caecum pulchellum, which together contributed nearly $70 \%$ to the average similarity of the group (Table 1). This area presented the lowest diversity (mean $\mathrm{H}^{\prime}=1.8 \pm \mathrm{SE} 0.6$ ), the greatest mean number of species found (mean $\mathrm{S}=39.0 \pm \mathrm{SE}$ 8.7 species) and the lowest evenness of all areas (mean $\mathrm{J}^{\prime}=0.5 \pm \mathrm{SE} 0.1$ ) (Appendix A, Table A3).

Table 1. Similarity percentages (SIMPER) of the most representative macrofaunal species (up to $90 \%$ cumulative contribution) collected in the three zones of the study area in summer. Average abundance is given in individuals $\mathrm{m}^{-2}$. Sim./SD is the ratio of average similarity divided by its standard deviation (SD).

\begin{tabular}{|c|c|c|c|c|c|}
\hline Species & Average Abundance & Average Similarity & Sim./SD & Contribution (\%) & Cumulative Contribution (\%) \\
\hline \multicolumn{6}{|c|}{ Sand-Average Similarity: 36.03} \\
\hline Exogone arenosa & 142.00 & 16.43 & 3.75 & 45.58 & 45.58 \\
\hline Caecum pulchellum & 136.33 & 8.77 & 0.58 & 24.33 & 69.91 \\
\hline Pholoe sp. & 23.67 & 3.78 & 8.60 & 10.49 & 80.41 \\
\hline Mactra sp. & 13.67 & 1.22 & 0.58 & 3.39 & 83.80 \\
\hline Kinbergonuphis sp. & 5.00 & 0.60 & 3.14 & 1.67 & 85.47 \\
\hline Corbula caribaea & 15.33 & 0.57 & 1.01 & 1.59 & 87.06 \\
\hline Pseudorythoe ambigua & 4.00 & 0.46 & 7.13 & 1.29 & 88.34 \\
\hline Ophiuroidea & 5.67 & 0.44 & 1.32 & 1.21 & 89.55 \\
\hline Caecum sp. & 4.00 & 0.41 & 0.58 & 1.13 & 90.69 \\
\hline \multicolumn{6}{|c|}{ Transition-Average Similarity: $\mathbf{5 2 . 5 2}$} \\
\hline Pholoe sp. & 51.33 & 31.32 & 3.38 & 59.64 & 59.64 \\
\hline Nucula semiornata & 7.67 & 3.88 & 2.46 & 7.38 & 67.02 \\
\hline Semelidae sp. & 7.00 & 2.42 & 0.58 & 4.60 & 71.62 \\
\hline Ampelisca cristata & 5.67 & 2.00 & 0.90 & 3.81 & 75.43 \\
\hline Caecum pulchellum & 2.00 & 1.46 & 29.01 & 2.79 & 78.22 \\
\hline Diplodonta punctata & 4.33 & 1.45 & 0.58 & 2.76 & 80.98 \\
\hline Lysidice schmardae & 6.33 & 1.44 & 1.19 & 2.75 & 83.73 \\
\hline Corbula caribaea & 4.00 & 1.21 & 0.58 & 2.30 & 86.03 \\
\hline Idunella titinga & 3.00 & 1.01 & 0.58 & 1.93 & 87.96 \\
\hline Cumacea & 2.67 & 0.97 & 2.46 & 1.85 & 89.80 \\
\hline Chione paphia & 1.00 & 0.73 & 29.01 & 1.39 & 91.20 \\
\hline \multicolumn{6}{|c|}{ Mud-Average Similarity: 43.63} \\
\hline Ophiuroidea & 8.67 & 21.24 & 12.49 & 48.68 & 48.68 \\
\hline Monokalliapseudes schubarti & 4.67 & 7.18 & 0.87 & 16.46 & 65.14 \\
\hline Harmothoe sp. & 2.67 & 5.91 & 4.98 & 13.54 & 78.68 \\
\hline Rathbunixa sayana & 1.33 & 1.85 & 0.58 & 4.24 & 82.92 \\
\hline Nereididae sp. & 1.33 & 0.93 & 0.58 & 2.12 & 85.05 \\
\hline Cabira incerta & 0.67 & 0.82 & 0.58 & 1.89 & 86.93 \\
\hline Maldanidae sp. & 2.00 & 0.82 & 0.58 & 1.89 & 88.82 \\
\hline Pseudoharpinia dentata & 0.67 & 0.82 & 0.58 & 1.89 & 90.70 \\
\hline
\end{tabular}


Sediments from the transition zone were composed mainly by fine and very fine sand with high calcium carbonate content ( $80 \%$; Appendix A, Table A1). The average similarity of the group was related mainly with the presence of the polychaete Pholoe sp. and the bivalve Nucula semiornata, which together contributed $67 \%$ to the group. Diversity was higher than in the other two areas (mean $\mathrm{H}^{\prime}=2.5 \pm \mathrm{SE} 0.1$ ) and the mean number of species was $32.3 \pm \mathrm{SE} 1.7$ (Appendix A, Table A3).

In the mud zone, fine-grained sediments were more prominent and higher silt and clay contents were found (Appendix A, Table A1). A species of unidentified ophiuroid, the tanaid Monokalliapseudes schubarti and the polychaete Harmothoe sp., accounted for nearly $80 \%$ of the average similarity in the group. Despite the lower number of species found in this zone (mean $S=16.0 \pm \mathrm{SE} 1.5$ species), diversity was relatively high (mean $\mathrm{H}^{\prime}=2.4 \pm \mathrm{SE} 0.1$ ), owing to the more even distribution of total abundance among species (Appendix A, Table A3).

In terms of species composition and abundance, macroinfaunal communities differed significantly among the three sedimentary zones (PERMANOVA Pseudo-F $=4.35, \mathrm{df}=2, p(\mathrm{MC})<0.01$ ) Appendix A, Table A4). The communities in sand and transition zones were more similar to each other (SIMPER average dissimilarity of $84 \%$; (PERMANOVA $t$-test, $p(\mathrm{MC})=0.11$ ), whereas the mud area was around $97 \%$ dissimilar to the other two sampled areas (PERMANOVA $t$-test, $p(\mathrm{MC})<0.02$ ) (Figure 2). Abundance was significantly different among the three sedimentary zones $(F=130.39$; $\mathrm{df}=2 ; p<0.001)$.

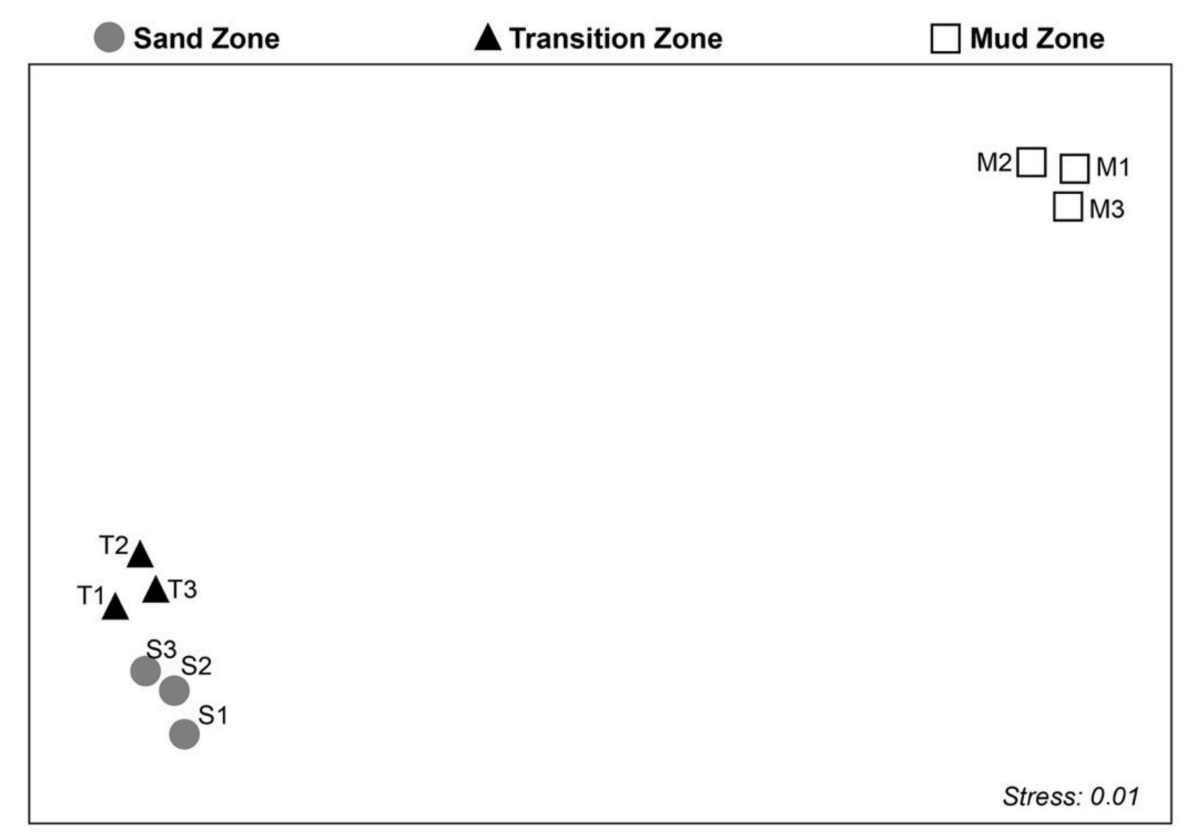

Figure 2. Non-metric Multidimensional Scaling (nMDS) showing the differences among the composition of macroinfaunal communities on the three sampling zones in summer. Numbers after $S$ (Sand Zone), $\mathrm{T}$ (transition Zone) and M (Mud Zone) represent the van Veen grab replicate $(n=3)$ of each zone.

\subsection{Upogebia Noronhensis Distribution}

$U$. noronhensis individuals were rare in the sand zone, being found only in summer $\left(0.6 \pm 0.4\right.$ ind. $\mathrm{m}^{-2}$; Table A1). The scarcity of animals prevented us from calculating a dispersion index for $U$. noronhensis in this area. The highest numerical densities were found in the transition zone with an average of approximately $144.6 \pm 13.8$ ind. $\mathrm{m}^{-2}$. In the mud zone, the mean density was nearly three times lower than those found in the transition zone, i.e., approximately $53.8 \pm 3.1$ ind. $\mathrm{m}^{-2}$ (Figure 3). There were no significant differences in $U$. noronhensis densities in summer and winter (two-way ANOVA, $\left.\mathrm{F}_{\text {season }}=0.14 ; \mathrm{df}=1 ; p=0.7140\right)$, but the total number of individuals was significantly higher in the transition zone (two-way ANOVA, $\mathrm{F}_{\mathrm{zone}}=57.25 ; \mathrm{df}=1 ; p<0.001$ ). There was no significant 
interaction between sediment zones and season (two-way ANOVA, $\mathrm{F}_{\text {zone.season }}=0.15 ; \mathrm{df}=1 ; p=0.6989$ ). There was no correlation between the number of $U$. noronhensis and macrofaunal density in the study area (Figure 3).

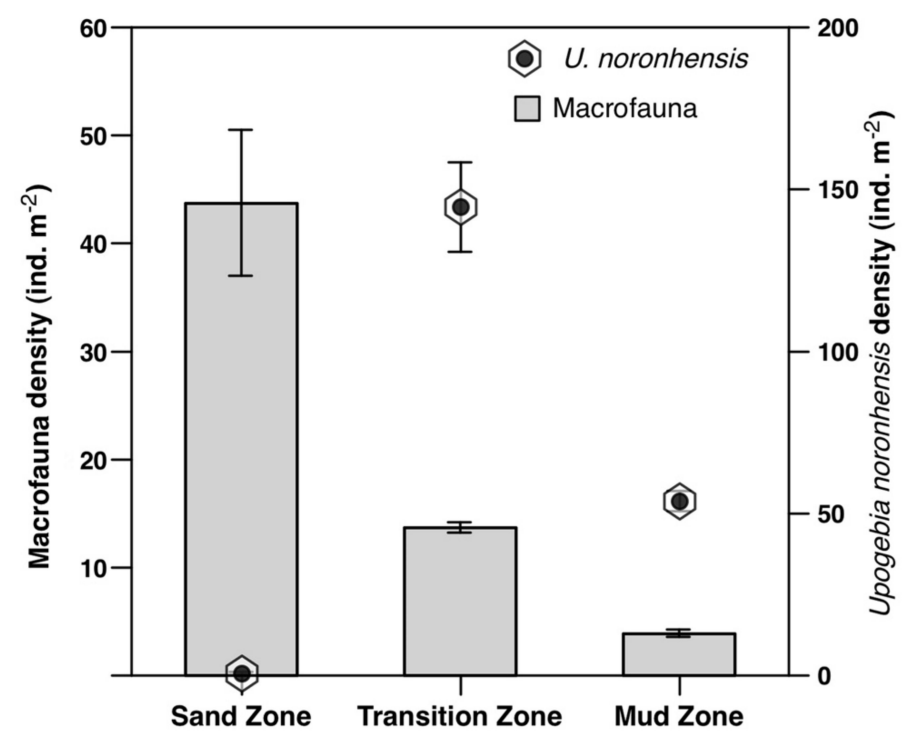

Figure 3. Macroinfaunal $\left(\mathrm{n}=3\right.$, per zone) and $U$. noronhensis $\left(\mathrm{n}=9\right.$, per zone) densities (ind. $\left.\mathrm{m}^{-2}\right)$ in the Table 1.

The distribution pattern of $U$. noronhensis within the zones (except in the sand zone where few or no animals were found) was aggregated (Table A1). Values of Standardized Morisita Index $\left(I_{p}\right)$ were around 0.5 in both the transition and mud zones, suggesting a clumped distribution. No differences in the burrow structure and shape between sediment zones were observed from the casts. The main difference was the shortening or bending of the lower central shaft of the common Y-shaped gallery due the presence of a gravel and deep shell layer $(\sim 10 \mathrm{~cm})$ in the transition zone.

The comparison of the two methods of $U$. noronhensis density assessment has been validated with a significant correlation between the direct individual count from resin casts and the indirect method of burrow opening counts $\left(\mathrm{N}_{(\text {pairs })}=10 ; \mathrm{r}_{\text {(Pearson) }}=0.67 ; \mathrm{p}=0.03\right)$.

$U$. noronhensis abundance measurements along a continuous transect showed that this species occurred starting at the $55 \mathrm{~m}$ (8.1 $\mathrm{m}$ depth) of the transect, increasing in numbers to reaching up to 252 ind. $\mathrm{m}^{-2}$ at the $106 \mathrm{~m}$ (10.1 m depth) in the transition zone and decreasing again towards the mud zone (Figure 3; Appendix A, Table A5). Testing for a preferred type of sediment grain size, there was a positive correlation between $U$. noronhensis abundance and fine sand $\left(\mathrm{N}_{(\text {pairs })}=34 ; \mathrm{r}_{(\text {Pearson })}=0.47\right.$; $p<0.01)$ and calcium carbonate $\left(\mathrm{N}_{(\text {pairs })}=34 ; \mathrm{r}_{\text {(Pearson) }}=0.49 ; p<0.01\right)$ content (Figure 4; Appendix A, Table A5).

The granulometric gradient in the sampling area was evident as shown in Figure 4. The sand zone had a higher coarse grain and lower OM and calcium carbonate contents. The transition zone was mostly composed of finer fractions of sand, low OM and higher calcium carbonate. The mud zone was mostly composed of silt and significant fractions of clay and very fine sand with high OM and calcium carbonate contents. Compared to the grain size composition of the area, the burrow walls were lined with finer particles (clay, silt, very fine sand and fine sand) and a lower content of coarse and very coarse sand than adjacent sediments (Figures 4 and 5). Additionally, the total organic matter contents were higher in the walls of a burrow (ca. $0.7 \%$ ) than in non-wall sediments (ca. $0.4 \%$ ) from samples adjacent to the burrows (Appendix A, Table A5). 


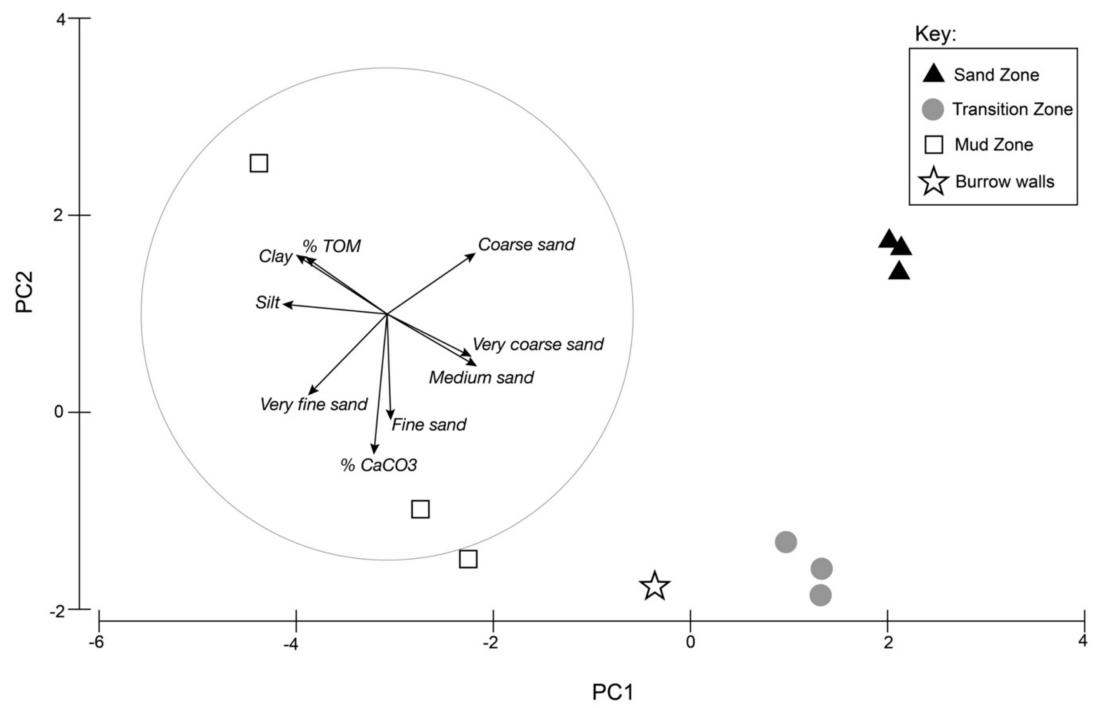

Figure 4. PCoA plot showing the sediment characteristics (vectors) for the three sampled sediment zones and for the burrow walls (symbols) in the autumn sampling. The first (PC1) and second (PC2) axes explain $55.5 \%$ and $30.0 \%$ of the total variation, respectively.

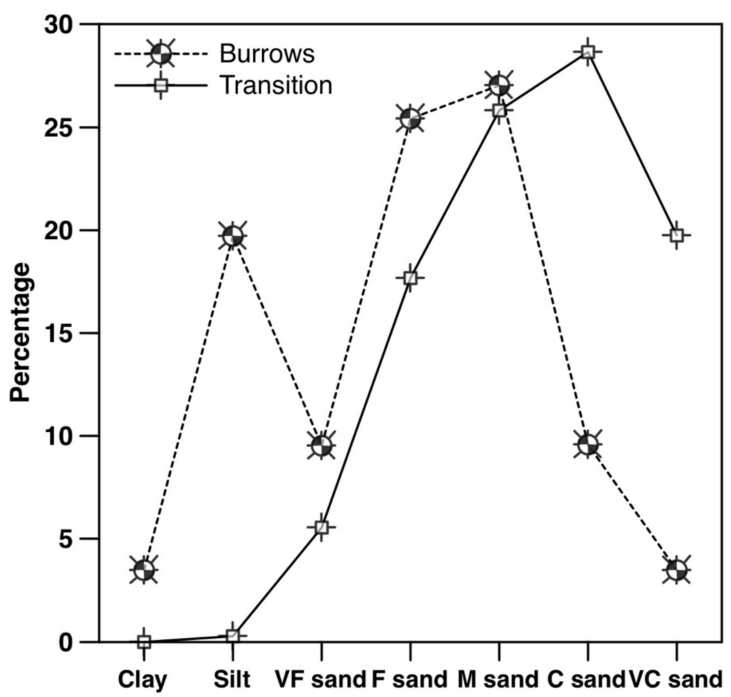

Figure 5. Percentage distribution of the several sediment grain size classes of the $U$. noronhensis burrow walls and adjacent sediments of the transition zone. VF sand = very fine sand; F sand = fine sand; $\mathrm{M}$ sand = medium sand $\mathrm{C}$ sand $=$ coarse sand $; \mathrm{VC}$ sand $=$ very coarse sand.

\section{Discussion}

This work presented the distribution of the thalassinidean $U$. noronhensis along a sedimentary and depth gradient of a shallow subtidal area on the SE Brazilian coast and characterized the macrofaunal species composition and abundance in each main sediment zone. The effect of the presence of this burrowing shrimp on the local fauna is an open issue to be investigated. Nevertheless, the higher densities of $U$. noronhensis found in the transition zone may affect the local fauna as a less dense but more diverse and richer community of infauna was found in the transition zone in comparison to the sand and mud zones, also suggested in discussions on the effects of thalassinids on the benthic fauna $[14,20]$. However, we should emphasize that the change in faunal composition is also combined with the change in the sediment type between zones and this study was not designed to isolate the effect of sediment type from mud shrimp influence. Additionally, the granulometric characteristics of 
the sediment change with depth. Coarser sediment are usually found in shallower areas close to the shore, whereas finer sediments tend to accumulate in the deeper areas in the center of the bays in the region, influencing the macrofauna distribution [35-37].

The macroinfaunal community found in the three sedimentary zones were typical for the SE Brazilian coast. The syllid polychaete Exogone arenosa is commonly associated with coarse sand substrate [38-40] as is the deposit feeder mollusk Caecum pulchellum [40]. The carnivorous polychaete Pholoe sp. was common in the sand zone and dominant in the transition zone [41,42]. Several bivalve species were present in the transition zone; the most important were semelids and Nucula semiornata, a typical deposit-feeder from shallow waters, found in a wide range of granulometric gradients $[43,44]$. The mud zone was characterized by the presence of ophiuroids and the tube-dwelling tanaid Monokalliapaseudes schubarti, a species that is associated with fine and organic-enriched sediments in the region $[45,46]$. Mud dwelling predators such as the polynoid polychaete Harmothoe sp. and the pinnotheridae crab Rathbunixa sayana were also common in the mud zone [40,47]. Several species of pinnotherid crabs are reported as commensals in thalassinidean burrows [48-50] but we found no direct evidence of $R$. sayana living in the burrows along with $U$. noronhensis.

Sediment reworking rates found for $U$. pugettensis suggests that $U$. noronhensis may generate high bioturbation due to their whole-year mating behavior, as males become more active in building new galleries when searching for a partner $[24,26,51]$. Therefore, $U$. noronhensis burrowing activities may still be sufficient to affect the surrounding fauna in zones of high abundances such as those observed in this study (ca. 140 ind. $\mathrm{m}^{-2}$ in average), particularly given the higher densities previously observed in the same area (ca. 200 ind. $\mathrm{m}^{-2}$ ) [20,24,26,48]. Similarly, the bioturbation of Upogebia pugettensis is known to strongly affect the macroinfauna of tidal flats of the northwest coast of the United States [26]. A recent review by Pillay [20] notes the non-linearity of the response of the macroinfauna abundance and richness to the thalassinid density, which can be modulated by factors such as sediment type or benthic organisms considered (epifauna or infauna). In addition to shrimp abundance and richness, the bioturbation rate may also vary seasonally as evidence gathered for $U$. noronhensis indicates that these animals must be reworking more sediment than previously thought, particularly during the spring and summer months when mating activities are more intense [24].

$U$. noronhensis preferentially inhabited poorly sorted sediments with higher contents of fine and very fine sand (more than $80 \%$ ) and calcium carbonate. The presence of fine grains is likely to be essential for the construction of the burrow, which was mainly composed of the smaller fraction of the sand and silt (see Figure 4). Our results pointed out that a high content of coarse sand in the sediment $(<80 \%)$ may be too unstable for building and maintaining burrows, whereas sediments with more than $40 \%$ of clay and silt content may not be as suitable for these filter-feeding organisms. However, the transition zone is characterized by moderate contents of fine-grained material, which $U$. noronhensis uses to build its burrow. Fine grains may be glued together by the animal through an organic mucous matrix, which, together with the adhesion of organic debris, phytoplankton, benthic microalgae and other heterotrophic microorganisms [52,53], increase the organic content of the burrow wall (see [3,7,54]). It has been noted that the burrow walls may also trap finer sediment and food particles on which mud shrimp could feed $[55,56]$. We found the content of total organic matter $75 \%$ higher in U. noronhensis burrows when compared with the background sediment. In comparison, Dworschak [57] did not find significant differences in the organic content of burrows and the surrounding sediment and argued that a mucus lining is improbable for U. pusilla. However, there is mounting evidence showing that burrow walls have a higher content of organic matter than the surrounding sediment $[7,52,53,55,56,58,59]$, suggesting that thalassinid shrimps may use food particles trapped on the burrow linings to feed $[53,55,56,60]$. We observed that $U$. noronhensis spends part of its time tending the burrow with sediment grains selected by its mouthparts (personal observation). This process may account for the selection of determinate grain sizes; $U$. noronhensis selected some particles to include in the burrow wall while rejecting others. It may also account for the inclusion of an organic secretion on the sediment grains just before tending the burrow. Of note, MacGinitie [61] observed $U$. pugettensis attaching loose sand 
onto a glass tube, arguing that this would be impossible without some sort of cementing material involved. This question, however, remains to be tested explicitly. This burrow tending may also be related to the use of the burrow lining as a food source, suggesting that part of the animal diet may rely on deposit feeding, supplementing filter feeding. Many authors have observed this same behavior in related species, such as Austinogebia edulis, Upogebia pugettensis, $U$. major and U. omissa $[52,55,56,60]$. Griffen et al. [55] argued that burrow lining feeding may be especially important for smaller and younger individuals, as the area-volume ratio of the burrow wall surface versus the burrow lumen is higher for smaller individuals than found in adult burrows, therefore trapping significantly more food particles on the walls. This may also compensate for the smaller pumping capacity of smaller individuals [62], who may not rely as much on filter feeding as adults do. Besides filter feeding, Bosley et al. [58] found that $U$. pugettensis also feed on benthic organic particulates, although no direct evidence from molecular markers (stable isotopes and fatty acids) indicated that the source was also from the burrow linings. Given the evidence in this study from granulometry and organic matter content in burrow linings, we should also consider $U$. noronhensis as a species that is both filter and deposit feeding, including on the burrow lining.

Total abundance of mud shrimp was estimated through burrow opening counts, which is a rapid and reliable method [63-65]. Density estimates using a burrow to animal ratio of 1.8/1 ([24], for the same species and area) were up to 250 ind. $\mathrm{m}^{-2}$, similar to values found by Dworschak [66] and Hodgson et al. [67] for other Upogebia species. Burrow densities as high as 200 burrow openings per square meter for $U$. omissa have been reported [60]. Samples collected in the present study using the resin casting technique yielded abundance estimates from $10 \%$ to three times higher than those collected through burrow opening counts in the same sediment type (see Table A5). However, density estimates derived from casts are likely overestimated, as the castings were conducted mostly in the transition zone, where the shrimp densities are higher. In contrast, van Veen grab samples tended to underestimate $U$. noronhensis densities. For all nine van Veen grab samples collected in the present study, we obtained over 1800 specimens of macrofaunal organisms; only four of them were $U$. noronhensis. In the transition zone, where thalassinid densities were highest, only two animals were collected in three van Veen replicates. Both of them were small juveniles, which have much smaller and shallower burrows; larger animals are nearly impossible to collect using these remote samplers because adults mud shrimps can quickly retreat deeper into the burrow, out of the sampling device reach. Larger sampling efforts undertaken elsewhere with similar gear also failed to sample another species of upogebiid thalassinidean, $U$. deltaura [68], showing the difficulty in conducting studies that involve the relationships between macrofauna structure and large populations of bioturbators such as upogebiids.

The high abundances of $U$. noronhensis found in the study area, especially in the transition zone, are likely to also be related to other sedimentary and biological issues. U. noronhensis galleries normally reach sediment depths up to 18 centimeters [24]; in the transition zone, a layer rich in shell fragments is found below 10 centimeters, which may further help stabilizing galleries. Interestingly, nearby areas with similar granulometric characteristics but without the deep shell layer did not harbor large numbers of $U$. noronhensis (personal observation). In addition, the dispersion pattern of $U$. noronhensis was aggregated both within and across the sediment zones. Evidence from the same species within the study area suggest juveniles settle on adult burrows [24], which is probably the main mechanism generating such dispersal and producing high densities. U. noronhensis may achieve high densities $\left(>120\right.$ ind. $\mathrm{m}^{-2}$ ) when sediment grain composition is ideal. Considering the clumped distribution and high densities attained in the region and the mud shrimp sediment reworking through burrowing, gallery maintenance and feeding activity, the role of $U$. noronhensis is likely to be significantly affecting the adjacent macroinfauna abundance and composition. These effects have yet to be directly proven with an experimental approach, such as with experiments using exclusion and transplant of the mud shrimp $[26,65,69,70]$. Although more direct evidence is needed, all these characteristics make $U$. noronhensis an important potential candidate as an ecosystem engineer in finer grained shallow unconsolidated areas in the southeastern Brazilian coast. 
Author Contributions: Conceptualization, P.Y.G.S. and A.M.S.P.-V.; methodology, P.Y.G.S.; formal analysis, P.Y.G.S., C.O.Q. and A.Z.G.; resources, A.M.S.P.-V.; data curation, P.Y.G.S. and A.Z.G.; writing一original draft preparation, P.Y.G.S.; writing-review and editing, P.Y.G.S., C.O.Q., A.Z.G. and A.M.S.P.-V.; visualization, P.Y.G.S. and A.Z.G.; supervision, A.M.S.P.-V. All authors have read and agreed to the published version of the manuscript.

Funding: P.Y.G.S. benefited from a grant by Conselho Nacional de Desenvolvimento Científico e Tecnológico (CNPq) grant number 301554/2019-6.

Acknowledgments: We thank Luciano Candisani for invaluable help in the field work and the support of the crew of the R.V. Veliger and the team from "Clarimundo de Jesus" Research Station, Instituto Oceanográfico da Universidade de São Paulo. We also thank Miguel Mies, Linda Waters and anonymous reviewers for reviewing and greatly improving the manuscript.

Conflicts of Interest: The authors declare no conflict of interest.

\section{Appendix A}

Table A1. Upogebia noronhensis $(\mathrm{n}=9)$ mean density (ind. $\mathrm{m}^{-2} \pm \mathrm{SE}$ ), Standardized Morisita Index $\left(I_{p}\right)$ $(\mathrm{n}=18)$ and sediment parameters in the three sample zones during the summer and winter periods. Sand classes: VF sand = very fine sand; $F$ sand = fine sand; $M$ sand = medium sand; $C$ sand = coarse sand; VC sand = very coarse sand.

\begin{tabular}{ccccccc}
\hline & \multicolumn{3}{c}{ Summer } & \multicolumn{3}{c}{ Winter } \\
\cline { 2 - 7 } & Sand & Transition & Mud & Sand & Transition & Mud \\
\hline U. noronhensis & $0.6 \pm 0.42$ & $144.6 \pm 13.82$ & $53.8 \pm 3.10$ & 0 & $135.9 \pm 14.54$ & $54.1 \pm 10.38$ \\
(ind. m ${ }^{-2} \pm$ SD) & $-0.61^{*}$ & 0.50 & 0.50 & ${\mathrm{n} / \mathrm{a}^{+}}^{+}$ & 0.50 & 0.51 \\
$I_{p}$ & uniform * & aggregated & aggregated & $\mathrm{n}^{+} \mathrm{a}^{+}$ & aggregated & aggregated \\
Distribution & 7 & 10 & 14 & 7 & 10 & 14 \\
Depth (m) & 13.7 & 5.4 & 0.5 & 5.9 & 11.3 & 2.2 \\
VC sand (\%) & 42.2 & 9.0 & 2.8 & 46.1 & 14.2 & 6.4 \\
C sand (\%) & 37.5 & 11.5 & 5.7 & 40.4 & 21.3 & 10.0 \\
M sand (\%) & 6.1 & 20.2 & 6.5 & 6.6 & 38.5 & 15.3 \\
F sand (\%) & 0.6 & 20.1 & 8.0 & 0.5 & 11.3 & 30.0 \\
VF sand (\%) & 0 & 21.3 & 57.4 & 0.1 & 0 & 31.0 \\
Silt (\%) & 0 & 12.1 & 19.1 & 0 & 0 & 5.2 \\
Clay (\%) & 54.2 & 79.9 & 60.9 & 61.6 & 80.4 & 78.6 \\
CaCO 3 (\%) & 54.9 &
\end{tabular}

* Very low mud shrimp density, only three quadrats had burrow openings; ${ }^{\dagger}$ not available, no burrow openings counted.

Table A2. Macrofaunal species collected in the three zones (Sand, Transition and Mud) of the study area. Numbers are in ind. $0.01 \mathrm{~m}^{-2}$. R1, R2 and R3 refer to the van Veen grab replicate $(\mathrm{n}=3)$ of a given area.

\begin{tabular}{|c|c|c|c|c|c|c|c|c|c|}
\hline \multirow{3}{*}{ Taxon } & \multicolumn{9}{|c|}{ Zones } \\
\hline & \multicolumn{3}{|c|}{ Sand } & \multicolumn{3}{|c|}{ Transition } & \multicolumn{3}{|c|}{ Mud } \\
\hline & R1 & $\mathbf{R} 2$ & R3 & R1 & $\mathbf{R} 2$ & R3 & R1 & $\mathbf{R} 2$ & R3 \\
\hline \multicolumn{10}{|l|}{ GASTROPODA } \\
\hline Caecum pulchellum & 0 & 280 & 129 & 2 & 2 & 2 & 0 & 0 & 0 \\
\hline Caecum sp. & 0 & 6 & 6 & 0 & 0 & 0 & 0 & 0 & 0 \\
\hline Aesopus stearnsi & 1 & 0 & 0 & 0 & 0 & 0 & 0 & 0 & 0 \\
\hline Turbonilla dispar & 0 & 1 & 0 & 0 & 0 & 0 & 0 & 0 & 0 \\
\hline Turbonilla sp. & 0 & 1 & 0 & 0 & 1 & 0 & 0 & 0 & 0 \\
\hline Alvania auberiana & 0 & 1 & 0 & 0 & 0 & 0 & 0 & 0 & 0 \\
\hline Assiminea succinea & 0 & 1 & 0 & 0 & 0 & 0 & 0 & 0 & 0 \\
\hline Macromphalina argentina & 0 & 1 & 1 & 0 & 0 & 0 & 0 & 0 & 0 \\
\hline Natica sp. & 0 & 4 & 0 & 0 & 0 & 0 & 0 & 0 & 0 \\
\hline Vitrinella sp. & 0 & 1 & 2 & 0 & 6 & 1 & 0 & 0 & 0 \\
\hline Bulla striata & 0 & 0 & 5 & 3 & 1 & 0 & 0 & 0 & 0 \\
\hline Calyptraea centralis & 0 & 0 & 1 & 0 & 0 & 0 & 1 & 0 & 0 \\
\hline Fissurellidae sp. & 0 & 1 & 1 & 0 & 0 & 0 & 0 & 0 & 0 \\
\hline Not identified & 0 & 0 & 1 & 0 & 0 & 0 & 0 & 0 & 0 \\
\hline
\end{tabular}


Table A2. Cont.

\begin{tabular}{|c|c|c|c|c|c|c|c|c|c|}
\hline \multirow{3}{*}{ Taxon } & \multicolumn{9}{|c|}{ Zones } \\
\hline & \multicolumn{3}{|c|}{ Sand } & \multicolumn{3}{|c|}{ Transition } & \multicolumn{3}{|c|}{ Mud } \\
\hline & R1 & $\mathbf{R} 2$ & R3 & R1 & $\mathbf{R} 2$ & R3 & R1 & R2 & R3 \\
\hline \multicolumn{10}{|l|}{ BIVALVIA } \\
\hline Puberella crenata & 1 & 0 & 0 & 0 & 0 & 0 & 0 & 0 & 0 \\
\hline Lirophora paphia & 0 & 4 & 0 & 1 & 1 & 1 & 0 & 0 & 0 \\
\hline Crassinella marplatensis & 1 & 1 & 1 & 0 & 0 & 0 & 0 & 0 & 0 \\
\hline Corbula caribaea & 1 & 39 & 6 & 0 & 5 & 7 & 0 & 0 & 1 \\
\hline Corbula cubaniana & 0 & 0 & 0 & 0 & 0 & 0 & 1 & 0 & 5 \\
\hline Corbula patagonica & 0 & 0 & 0 & 0 & 0 & 0 & 0 & 1 & 2 \\
\hline Corbula sp. & 0 & 0 & 2 & 0 & 0 & 0 & 0 & 1 & 0 \\
\hline Abra aequalis & 1 & 0 & 0 & 0 & 0 & 0 & 0 & 0 & 0 \\
\hline Abra lioica & 1 & 0 & 0 & 0 & 0 & 0 & 0 & 0 & 0 \\
\hline Abra sp. & 0 & 3 & 8 & 5 & 0 & 0 & 0 & 0 & 0 \\
\hline Macoma sp. & 1 & 0 & 0 & 0 & 0 & 0 & 0 & 0 & 0 \\
\hline Tellina sp. & 1 & 3 & 4 & 1 & 1 & 0 & 0 & 0 & 4 \\
\hline Ervilia sp. & 3 & 0 & 0 & 0 & 0 & 0 & 0 & 0 & 0 \\
\hline Pitar fulminatus & 0 & 4 & 30 & 1 & 1 & 0 & 0 & 0 & 0 \\
\hline Pitar rostratus & 0 & 1 & 1 & 1 & 0 & 1 & 0 & 0 & 0 \\
\hline Chama sp. & 0 & 4 & 2 & 0 & 0 & 0 & 0 & 0 & 0 \\
\hline Nucula semiornata & 0 & 1 & 0 & 11 & 4 & 8 & 0 & 0 & 0 \\
\hline Thracia similis & 0 & 3 & 4 & 1 & 0 & 5 & 0 & 0 & 0 \\
\hline Phacoides pectinata & 0 & 1 & 0 & 0 & 0 & 0 & 0 & 0 & 0 \\
\hline Mactra sp. & 0 & 23 & 18 & 1 & 1 & 0 & 0 & 0 & 0 \\
\hline Lioberus castaneus & 0 & 0 & 1 & 0 & 0 & 0 & 0 & 0 & 0 \\
\hline Diplodonta punctata & 0 & 0 & 0 & 0 & 7 & 6 & 0 & 0 & 0 \\
\hline Glycymeris sp. & 0 & 0 & 1 & 0 & 0 & 0 & 0 & 0 & 0 \\
\hline Pandora bushiana & 0 & 0 & 0 & 2 & 0 & 0 & 0 & 0 & 0 \\
\hline Entodesma patagonicum & 0 & 0 & 0 & 1 & 0 & 1 & 0 & 0 & 0 \\
\hline Clathrolucina costata & 0 & 0 & 0 & 1 & 0 & 1 & 0 & 0 & 0 \\
\hline Trachycardium muricatum & 0 & 0 & 0 & 2 & 0 & 0 & 0 & 0 & 0 \\
\hline Anadara sp. & 0 & 0 & 0 & 0 & 0 & 0 & 0 & 0 & 1 \\
\hline Veneridae sp. & 1 & 27 & 0 & 0 & 0 & 0 & 0 & 0 & 0 \\
\hline Mytilidae sp. & 0 & 1 & 0 & 0 & 0 & 0 & 0 & 0 & 0 \\
\hline Lucinidae sp. & 0 & 1 & 0 & 0 & 0 & 0 & 0 & 0 & 0 \\
\hline Ungulinidae sp. & 0 & 5 & 2 & 1 & 0 & 0 & 0 & 0 & 0 \\
\hline Cardiidae sp. & 0 & 0 & 1 & 0 & 0 & 1 & 0 & 0 & 0 \\
\hline Carditidae sp. & 0 & 0 & 1 & 0 & 0 & 0 & 0 & 0 & 0 \\
\hline Tellinidae sp. & 0 & 0 & 0 & 1 & 0 & 0 & 0 & 0 & 0 \\
\hline Semelidae sp. & 0 & 0 & 0 & 0 & 11 & 10 & 0 & 0 & 1 \\
\hline \multicolumn{10}{|l|}{ SCAPHOPODA } \\
\hline Polyschides tetraschitus & 0 & 0 & 0 & 0 & 1 & 0 & 0 & 0 & 0 \\
\hline \multicolumn{10}{|l|}{ POLYPLACOPHORA } \\
\hline Ischnochiton sp. & 1 & 0 & 1 & 0 & 0 & 0 & 0 & 0 & 0 \\
\hline \multicolumn{10}{|l|}{ THALASSINIDEA } \\
\hline Upogebia noronhensis & 0 & 0 & 2 & 0 & 2 & 0 & 0 & 0 & 0 \\
\hline \multicolumn{10}{|l|}{ CARIDEA } \\
\hline Automate sp. & 0 & 2 & 0 & 0 & 0 & 0 & 0 & 0 & 0 \\
\hline Processa hemphilli & 0 & 0 & 0 & 0 & 1 & 0 & 0 & 2 & 0 \\
\hline Alpheus floridanus & 0 & 0 & 0 & 0 & 0 & 0 & 1 & 0 & 1 \\
\hline \multicolumn{10}{|l|}{ BRACHYURA } \\
\hline Tetraxanthus rathbunae & 0 & 1 & 0 & 0 & 0 & 0 & 0 & 0 & 0 \\
\hline Persephona mediterranea & 0 & 0 & 0 & 0 & 1 & 0 & 0 & 0 & 0 \\
\hline $\begin{array}{c}\text { Acantholobulus } \\
\text { bermudensis }\end{array}$ & 0 & 0 & 0 & 0 & 0 & 2 & 0 & 0 & 0 \\
\hline Rathbunixa sayana & 0 & 0 & 0 & 0 & 0 & 0 & 2 & 2 & 0 \\
\hline Xanthidae sp. & 0 & 0 & 1 & 0 & 0 & 0 & 0 & 0 & 0 \\
\hline AMPHIPODA & & & & & & & & & \\
\hline Tiburonella viscana & 1 & 0 & 0 & 0 & 1 & 0 & 0 & 0 & 0 \\
\hline Idunella titinga & 1 & 1 & 0 & 4 & 5 & 0 & 0 & 0 & 0 \\
\hline Ampelisca cristata & 0 & 7 & 3 & 10 & 6 & 1 & 0 & 1 & 0 \\
\hline Ampelisca pugetica & 0 & 0 & 0 & 0 & 0 & 1 & 0 & 0 & 0 \\
\hline
\end{tabular}


Table A2. Cont.

\begin{tabular}{|c|c|c|c|c|c|c|c|c|c|}
\hline \multirow{3}{*}{ Taxon } & \multicolumn{9}{|c|}{ Zones } \\
\hline & \multicolumn{3}{|c|}{ Sand } & \multicolumn{3}{|c|}{ Transition } & \multicolumn{3}{|c|}{ Mud } \\
\hline & $\mathbf{R} 1$ & $\mathbf{R} 2$ & R3 & $\mathbf{R} 1$ & $\mathbf{R} 2$ & R3 & R1 & $\mathbf{R 2}$ & R3 \\
\hline Phoxocephalopsis zimmeri & 0 & 4 & 0 & 0 & 0 & 0 & 0 & 0 & 0 \\
\hline Globosolembos smithi & 0 & 0 & 1 & 0 & 0 & 0 & 0 & 0 & 0 \\
\hline Photis longicaudata & 0 & 0 & 2 & 6 & 1 & 0 & 0 & 0 & 0 \\
\hline Ericthonius brasiliensis & 0 & 0 & 1 & 0 & 0 & 1 & 0 & 0 & 0 \\
\hline Monoculodes nyei & 0 & 0 & 0 & 1 & 0 & 0 & 0 & 0 & 0 \\
\hline Cheiriphotis megacheles & 0 & 0 & 0 & 0 & 0 & 2 & 0 & 0 & 0 \\
\hline Pseudoharpinia dentata & 0 & 0 & 0 & 0 & 0 & 0 & 1 & 0 & 1 \\
\hline Caprellidae sp. & 0 & 7 & 3 & 1 & 0 & 0 & 0 & 0 & 0 \\
\hline Lysianassidae sp. & 0 & 2 & 1 & 2 & 0 & 0 & 0 & 0 & 0 \\
\hline Isaeidae sp. & 0 & 0 & 2 & 0 & 0 & 0 & 0 & 1 & 0 \\
\hline Aoridae sp. & 0 & 0 & 3 & 0 & 0 & 1 & 0 & 0 & 0 \\
\hline Ampeliscidae sp. & 0 & 0 & 0 & 0 & 0 & 1 & 0 & 1 & 0 \\
\hline Not identified & 1 & 0 & 2 & 0 & 1 & 0 & 0 & 0 & 0 \\
\hline \multicolumn{10}{|l|}{ POLYCHAETA } \\
\hline Kinbergonuphis sp. & 2 & 9 & 4 & 0 & 0 & 0 & 0 & 0 & 0 \\
\hline Exogone arenosa & 281 & 65 & 80 & 0 & 3 & 5 & 0 & 0 & 0 \\
\hline Hermundura fauveli & 1 & 0 & 0 & 0 & 0 & 0 & 0 & 0 & 0 \\
\hline Lysidice schmardae & 1 & 8 & 3 & 4 & 1 & 14 & 0 & 0 & 0 \\
\hline Pseudorythoe ambigua & 2 & 2 & 8 & 0 & 4 & 0 & 0 & 0 & 0 \\
\hline Glicine multidens & 0 & 1 & 10 & 0 & 0 & 3 & 0 & 0 & 0 \\
\hline Syllis sp. & 0 & 0 & 7 & 1 & 0 & 0 & 0 & 0 & 0 \\
\hline Ninetta sp. & 0 & 0 & 1 & 0 & 0 & 0 & 0 & 0 & 0 \\
\hline Neanthes sp. & 0 & 0 & 0 & 0 & 3 & 0 & 0 & 0 & 0 \\
\hline Owenia fusiformis & 0 & 0 & 0 & 0 & 1 & 0 & 0 & 0 & 2 \\
\hline Magelona variolamellata & 0 & 0 & 0 & 0 & 14 & 2 & 0 & 0 & 0 \\
\hline Loandaria americana & 0 & 0 & 0 & 0 & 2 & 0 & 0 & 0 & 0 \\
\hline Lisidice ninetta & 0 & 0 & 2 & 0 & 1 & 1 & 0 & 0 & 0 \\
\hline Glicera americana & 0 & 0 & 0 & 0 & 0 & 1 & 0 & 0 & 0 \\
\hline Lumbrineris sp. & 0 & 0 & 0 & 0 & 1 & 0 & 0 & 0 & 0 \\
\hline Cabira incerta & 0 & 0 & 0 & 0 & 0 & 0 & 1 & 0 & 1 \\
\hline Harmothoe sp. & 0 & 0 & 0 & 0 & 0 & 0 & 2 & 3 & 3 \\
\hline Scoloplos (Leodamas) sp. & 0 & 0 & 0 & 0 & 0 & 0 & 3 & 0 & 0 \\
\hline Isolda pulchela & 0 & 0 & 0 & 0 & 0 & 0 & 0 & 1 & 0 \\
\hline Maldanidae sp. & 0 & 0 & 0 & 0 & 0 & 0 & 1 & 0 & 5 \\
\hline Nereididae sp. & 0 & 0 & 0 & 1 & 0 & 0 & 3 & 1 & 0 \\
\hline Spionidae sp. & 0 & 0 & 0 & 0 & 0 & 0 & 2 & 0 & 0 \\
\hline Pholoe sp. & 16 & 17 & 38 & 59 & 35 & 60 & 0 & 0 & 0 \\
\hline Sabellidae sp. & 0 & 0 & 0 & 0 & 0 & 1 & 0 & 0 & 0 \\
\hline Eunice sp. & 0 & 0 & 0 & 0 & 0 & 0 & 0 & 0 & 1 \\
\hline Euclimelia sp. & 0 & 0 & 0 & 0 & 0 & 0 & 0 & 6 & 0 \\
\hline Ancistrosyllis jonesi & 0 & 0 & 0 & 0 & 0 & 1 & 0 & 0 & 0 \\
\hline Notomastus lobatus & 0 & 0 & 0 & 0 & 0 & 0 & 0 & 0 & 2 \\
\hline $\begin{array}{l}\text { Terebellidae sp. } \\
\text { ISOPODA }\end{array}$ & 0 & 0 & 0 & 0 & 0 & 1 & 0 & 0 & 0 \\
\hline Munna cananeia & 0 & 0 & 0 & 1 & 0 & 1 & 0 & 0 & 0 \\
\hline Anthuridae sp. & 0 & 1 & 0 & 0 & 1 & 1 & 0 & 0 & 0 \\
\hline $\begin{array}{l}\text { Politolana sp. } \\
\text { TANAIDACEA }\end{array}$ & 0 & 0 & 0 & 0 & 0 & 0 & 1 & 0 & 0 \\
\hline $\begin{array}{c}\text { Monokalliapseudes } \\
\text { schubarti }\end{array}$ & 0 & 0 & 0 & 0 & 0 & 0 & 7 & 6 & 1 \\
\hline Tanais sp. & 0 & 1 & 1 & 4 & 0 & 1 & 0 & 0 & 0 \\
\hline CUMACEA sp. 1 & 0 & 0 & 2 & 5 & 1 & 2 & 0 & 0 & 0 \\
\hline HIRUDINEA sp. 1 & 0 & 0 & 1 & 0 & 0 & 0 & 0 & 0 & 0 \\
\hline OPHIUROIDEA sp. 1 & 1 & 12 & 4 & 0 & 1 & 0 & 9 & 8 & 9 \\
\hline ECHINOIDEA sp. 1 & 3 & 0 & 0 & 0 & 0 & 0 & 0 & 0 & 0 \\
\hline NEMERTINEA sp. 1 & 6 & 0 & 2 & 0 & 0 & 0 & 0 & 1 & 2 \\
\hline PRIAPULIDA sp. 1 & 0 & 0 & 3 & 0 & 0 & 0 & 0 & 0 & 0 \\
\hline ECHIURA sp. 1 & 0 & 0 & 0 & 0 & 0 & 0 & 0 & 0 & 3 \\
\hline ACTINIARIA sp. 1 & 0 & 0 & 4 & 0 & 0 & 0 & 0 & 2 & 1 \\
\hline PYCNOGONIDA sp. 1 & 0 & 2 & 1 & 0 & 1 & 0 & 0 & 0 & 0 \\
\hline Branchiostoma sp. & 0 & 2 & 1 & 0 & 1 & 0 & 0 & 0 & 0 \\
\hline TOTAL & 329 & 562 & 422 & 134 & 130 & 147 & 35 & 37 & 46 \\
\hline
\end{tabular}


Table A3. Macrofaunal community descriptors obtained for the three sampled zones and results for one-way ANOVA and post-hoc Tukey testing for differences among sediment zones. Numbers 1 to 3 are replicates. $\mathrm{S}=$ sand zone; $\mathrm{T}=$ transition zone; $\mathrm{M}=$ mud zone; $\mathrm{S}=$ species richness; $\mathrm{n}=$ total number of individuals; $\mathrm{J}^{\prime}=$ Pielou evenness index; $\mathrm{H}_{(\log \text { e) }}^{\prime}=$ Shannon diversity index. Mean and standard error (SE) are included for each descriptor in each zone. Asterisk $\left(^{*}\right)$ indicates significant $p$-values $(p<0.05)$. For Tukey pairwise tests, zones (S, T and M) linked with the same line are not statistically different.

\begin{tabular}{|c|c|c|c|c|c|}
\hline Zone & Sample & S & $\mathbf{n}$ & $\mathrm{J}^{\prime}$ & $H^{\prime}\left(\log _{e}\right)$ \\
\hline \multirow{4}{*}{ Sand } & S1 & 22 & 328 & 0.25 & 0.77 \\
\hline & S2 & 44 & 562 & 0.56 & 2.14 \\
\hline & S3 & 51 & 419 & 0.67 & 2.63 \\
\hline & Mean $( \pm S E)$ & $39 \pm 8.73$ & $436.33 \pm 68.10$ & $0.49 \pm 0.12$ & $1.84 \pm 0.55$ \\
\hline \multirow{4}{*}{ Transition } & $\mathrm{T} 1$ & 29 & 134 & 0.69 & 2.34 \\
\hline & $\mathrm{T} 2$ & 35 & 129 & 0.80 & 2.84 \\
\hline & $\mathrm{T} 3$ & 33 & 147 & 0.70 & 2.45 \\
\hline & Mean $( \pm S E)$ & $32.33 \pm 1.76$ & $136.66 \pm 5.36$ & $0.73 \pm 0.03$ & $2.54 \pm 0.15$ \\
\hline \multirow{4}{*}{ Mud } & M1 & 14 & 35 & 0.87 & 2.29 \\
\hline & M2 & 15 & 37 & 0.88 & 2.38 \\
\hline & M3 & 19 & 46 & 0.90 & 2.66 \\
\hline & Mean $( \pm S E)$ & $16.0 \pm 1.52$ & $39.33 \pm 3.38$ & $0.83 \pm 0.00$ & $2.44 \pm 0.11$ \\
\hline \multirow{3}{*}{ 1-way ANOVA } & $\mathrm{F}$ & 7.64 & 130.39 & 5.42 & 1.23 \\
\hline & $\mathrm{df}$ & 2 & 2 & 2 & 2 \\
\hline & $p$ & $0.02 *$ & $<0.001 *$ & 0.04 * & 0.35 \\
\hline Tukey & & S T M & S T M & M T S & T MS \\
\hline
\end{tabular}

Table A4. Results of the 1-way permutational multivariate analysis of variance (PERMANOVA) and pairwise $t$-tests using Bray-Curtis distances testing for differences on the composition of macroinfaunal communities among three sedimentary zones. $p$-values were adjusted using the Monte Carlo approach [ $p(\mathrm{MC})] . p$-values for tests of homogeneity of dispersion (PermDisp) are shown [ $p$ (PermDisp)]. Asterisk indicates values under $5 \%$ probability.

\begin{tabular}{|c|c|c|c|c|c|c|}
\hline Source & df & SS & MS & Pseudo-F & $p(\mathrm{MC})$ & $p($ PermDisp $)$ \\
\hline Zones & 2 & 15,414 & 7707.2 & 4.35 & $0.004 *$ & 0.959 \\
\hline Residual & 6 & 10,611 & 1768.4 & & & \\
\hline \multirow[t]{5}{*}{ Total } & 8 & 26,025 & & & & \\
\hline & $t$-test: & \multicolumn{2}{|c|}{ Groups } & $\mathrm{t}$ & $p(\mathrm{MC})$ & $p$ (PermDisp) \\
\hline & & Sand & Transition & 1.4906 & 0.117 & 1.00 \\
\hline & & Sand & Mud & 2.1955 & $0.018^{*}$ & 1.00 \\
\hline & & Transition & Mud & 2.4613 & 0.009 * & 0.202 \\
\hline
\end{tabular}

Table A5. U. noronhensis densities and sediment characteristics along the sampled transect in autumn. Sediment data are represented in percentages. Shaded rows represent data collected along with resin casts. Sand classes: VC sand = very coarse sand; $\mathrm{C}$ sand = coarse sand; $\mathrm{M}$ sand = medium sand; $\mathrm{F}$ sand $=$ fine sand; VF sand = very fine sand.

\begin{tabular}{|c|c|c|c|c|c|c|c|c|c|c|c|}
\hline $\begin{array}{l}\text { Transect Distance/ } \\
\text { Depth (m) }\end{array}$ & $\begin{array}{l}\text { Density } \\
{\text { (ind. } m^{-2} \text { ) }}^{\text {ind }}\end{array}$ & VC Sand & C Sand & M Sand & F Sand & VF Sand & Silt & Clay & Gravel & OM & $\mathrm{CaCO}_{3}$ \\
\hline $13 / 6.8$ & 0 & 2.2 & 70.8 & 23.2 & 3.5 & 0.3 & 0.1 & 0 & 0 & $<0.1$ & 61.8 \\
\hline $25 / 7.4$ & 0 & 7.8 & 41.2 & 44.9 & 6.6 & 0.7 & 0 & 0 & 0.9 & $<0.1$ & 70.9 \\
\hline $50 / 8.1$ & 0 & 19.4 & 26.5 & 31.1 & 12.2 & 5.1 & 0 & 0 & 5.7 & 0.2 & 77.9 \\
\hline $55 / 8.1$ & 11.1 & 12.4 & 21.2 & 40.1 & 19.9 & 3.2 & 0.1 & 0 & 2.7 & 0.1 & 78.4 \\
\hline $56 / 8.3$ & 56.7 & 23.3 & 22.7 & 32.8 & 13.8 & 3.1 & 0 & 0 & 4.3 & 0.1 & 80.3 \\
\hline $57 / 8.4$ & 78.9 & 18.7 & 25.9 & 34.9 & 12.4 & 1.9 & 0 & 0 & 6.1 & 0.2 & 81.6 \\
\hline $58 / 8.5$ & 67.8 & 11.3 & 22.5 & 45.8 & 17.0 & 1.4 & 0 & 0 & 2.1 & 0.1 & 83.1 \\
\hline $59 / 8.5$ & 125.0 & 7.3 & 14.5 & 44.6 & 23.5 & 7.2 & 0 & 0 & 2.9 & $<0.1$ & 84.1 \\
\hline $61 / 8.7$ & 186.7 & 13.8 & 20.1 & 35.1 & 20.4 & 6.0 & 0 & 0 & 4.7 & 0.2 & 81.2 \\
\hline $63 / 8.8$ & 250.0 & 13.5 & 27.7 & 40.7 & 15.9 & 1.6 & 0 & 0 & 0.7 & $<0.1$ & 82.6 \\
\hline $64 / 8.8$ & 92.2 & 9.9 & 18.9 & 41.1 & 21.0 & 5.2 & 0 & 0 & 3.9 & $<0.1$ & 81.0 \\
\hline $66 / 8.8$ & 100.0 & 8.0 & 16.7 & 36.4 & 31.0 & 7.4 & 0.4 & 0 & 0.3 & 0.2 & 80.9 \\
\hline $69 / 8.9$ & 300.0 & 11.6 & 17.7 & 33.8 & 28.1 & 5.4 & 0.1 & 0 & 3.3 & 0.3 & 80.9 \\
\hline
\end{tabular}


Table A5. Cont.

\begin{tabular}{|c|c|c|c|c|c|c|c|c|c|c|c|}
\hline $\begin{array}{l}\text { Transect Distance/ } \\
\text { Depth }(\mathrm{m})\end{array}$ & $\begin{array}{l}\text { Density } \\
{\text { (ind. }{ }^{-2} \text { ) }}^{\text {ind }}\end{array}$ & VC Sand & C Sand & M Sand & F Sand & VF Sand & Silt & Clay & Gravel & OM & $\mathrm{CaCO}_{3}$ \\
\hline $71 / 9.1$ & 104.4 & 13.3 & 19.2 & 32.1 & 27.8 & 5.9 & 0.2 & 0 & 1.4 & 0.1 & 80.6 \\
\hline $74 / 9.1$ & 155.6 & 11.3 & 15.4 & 32.5 & 26.8 & 9.2 & 0.4 & 0 & 4.5 & 0.2 & 82.2 \\
\hline $75 / 9.1$ & 375.0 & 5.4 & 11.5 & 26.5 & 32.6 & 8.8 & 15.3 & 0 & 0.0 & 0.1 & 81.1 \\
\hline $77 / 9.2$ & 350.0 & 8.5 & 13.7 & 30.7 & 31.8 & 11.5 & 0.1 & 0 & 0.4 & 0.3 & 81.1 \\
\hline $77 / 9.2$ & 124.4 & 14.8 & 19.4 & 29.5 & 27.0 & 7.6 & 0 & 0 & 1.8 & 0.1 & 83.2 \\
\hline $78 / 9.3$ & 38.9 & 8.2 & 11.9 & 22.0 & 29.2 & 8.5 & 19.8 & 0 & 0.4 & 0.2 & 79.3 \\
\hline $80 / 9.4$ & 48.9 & 7.7 & 13.7 & 34.0 & 35.5 & 9.1 & 0 & 0 & 0.1 & 0.1 & 82.3 \\
\hline $85 / 9.5$ & 54.4 & 13.6 & 21.7 & 27.9 & 25.3 & 5.4 & 0 & 0 & 6.1 & 0.1 & 84.3 \\
\hline $86 / 9.6$ & 31.1 & 10.1 & 18.5 & 21.8 & 16.1 & 12.1 & 17.8 & 0 & 3.5 & 0.2 & 83.0 \\
\hline $87 / 9.5$ & 210.0 & 8.1 & 11.2 & 22.4 & 29.0 & 8.8 & 19.8 & 0 & 0.7 & 0.2 & 82.0 \\
\hline $90 / 9.5$ & 60.0 & 19.0 & 22.1 & 21.8 & 19.9 & 9.2 & 0.1 & 0 & 7.9 & 0.2 & 83.6 \\
\hline $91 / 9.5$ & 132.2 & 15.5 & 22.8 & 25.7 & 20.5 & 10.2 & 0.7 & 0 & 4.6 & 0.1 & 82.6 \\
\hline $92 / 9.5$ & 200 & 11.9 & 20.0 & 23.6 & 20.0 & 6.5 & 8.5 & 9.3 & 0 & 0.5 & 79.4 \\
\hline $95 / 9.7$ & 165.6 & 11.3 & 20.9 & 20.6 & 13.8 & 11.5 & 12.0 & 5.9 & 3.8 & 0.2 & 83.2 \\
\hline $96 / 9.7$ & 325 & 12.2 & 14.3 & 15.9 & 21.0 & 9.9 & 12.7 & 11.0 & 3.1 & 0.3 & 81.8 \\
\hline $96 / 9.7$ & 145.6 & 5.0 & 14.3 & 17.3 & 24.5 & 10.2 & 17.9 & 5.5 & 1.3 & 0.2 & 81.9 \\
\hline $100 / 9.9$ & 77.8 & 5.4 & 13.8 & 18.5 & 24.3 & 14.2 & 22.6 & 0 & 1.2 & 0.2 & 81.3 \\
\hline $105 / 10.1$ & 121.1 & 11.0 & 17.5 & 17.4 & 22.1 & 12.7 & 18.2 & 0 & 1.0 & 0.2 & 82.7 \\
\hline $109 / 10.1$ & 225 & 4.7 & 11.8 & 14.2 & 24.1 & 16.0 & 23.5 & 5.3 & 0.3 & 0.2 & 78.5 \\
\hline 110/10.1 & 111.1 & 6.5 & 14.7 & 18.3 & 26.5 & 14.7 & 19.3 & 0 & 0 & 0.1 & 84.2 \\
\hline $112 / 10.3$ & 125.6 & 4.3 & 9.9 & 12.7 & 19.2 & 25.3 & 17.1 & 11.4 & 0 & 0.2 & 81.6 \\
\hline $114 / 10.4$ & 33.3 & 2.5 & 10.4 & 15.4 & 21.3 & 21.3 & 23.4 & 5.8 & 0 & 0.4 & 82.4 \\
\hline $115 / 10.4$ & 121.1 & 3.5 & 8.9 & 12.4 & 24.3 & 22.4 & 28.1 & 0.1 & 0.2 & 0.3 & 81.2 \\
\hline $118 / 10.5$ & 50.0 & 5.5 & 11.9 & 14.1 & 20.4 & 22.5 & 17.1 & 8.5 & 0 & 0.4 & 74.4 \\
\hline $119 / 10.0$ & 53.3 & 5.3 & 11.9 & 12.9 & 16.4 & 17.6 & 21.2 & 14.1 & 0.6 & 0.7 & 70 \\
\hline $120 / 10.1$ & 91.1 & 3.3 & 8.1 & 9.5 & 13.9 & 20.9 & 34.5 & 9.9 & 0 & 0.6 & 79.6 \\
\hline $122 / 10.4$ & 30.0 & 2.1 & 10.6 & 14.5 & 18.0 & 25.2 & 23.6 & 5.9 & 0 & 0.5 & 81.9 \\
\hline $127 / 11.1$ & 0.0 & 1.4 & 7.2 & 10.4 & 11.4 & 24.7 & 34.9 & 10.0 & 3.7 & 0.1 & 81.1 \\
\hline $129 / 11.2$ & 37.8 & 1.1 & 6.1 & 9.1 & 9.1 & 23.8 & 37.3 & 14.0 & 0 & 0.8 & 77.5 \\
\hline $130 / 11.4$ & 5.6 & 2.1 & 7.0 & 11.5 & 11.5 & 16.5 & 42.1 & 9.3 & 0 & 0.8 & 78.4 \\
\hline $133 / 11.8$ & 45.6 & 0.5 & 5.7 & 9.8 & 8.7 & 18.8 & 39.1 & 17.4 & 0 & 1.9 & 76.9 \\
\hline
\end{tabular}

\section{References}

1. Jones, C.G.; Lawton, J.H.; Shachak, M. Organisms as ecosystem engineers. Oikos 1994, 69, 373-386. [CrossRef]

2. Kristensen, E.; Penha-Lopes, G.; Delefosse, M.; Valdemarsen, T.; Quintana, C.O.; Banta, G.T. What is bioturbation? The need for a precise definition for fauna in aquatic sciences. Mar. Ecol. Prog. Ser. 2012, 446, 285-302. [CrossRef]

3. Kristensen, E.; Kostka, J.E. Macrofaunal Burrows and Irrigation in Marine Sediment: Microbiological and Biogeochemical Interactions. In Interactions between Macro- and Microorganisms in Marine Sediments; American Geophysical Union: Washington, DC, USA, 2005; pp. 125-157. ISBN 978-1-118-66544-2.

4. Gutiérrez, J.L.; Jones, C.G.; Groffman, P.M.; Findlay, S.E.G.; Iribarne, O.O.; Ribeiro, P.D.; Bruschetti, C.M. The contribution of crab burrow excavation to carbon availability in surficial salt-marsh sediments. Ecosystems 2006, 9, 647-658. [CrossRef]

5. Ziebis, W.; Forster, S.; Huettel, M.; Jorgensen, B.B. Complex burrows of the mud shrimp Callianassa truncata and their geochemical impact in the sea bed. Nature 1996, 382, 4. [CrossRef]

6. D'Andrea, A.F.; DeWitt, T.H. Geochemical ecosystem engineering by the mud shrimp Upogebia pugettensis (Crustacea: Thalassinidae) in Yaquina Bay, Oregon: Density-dependent effects on organic matter remineralization and nutrient cycling. Limnol. Oceanogr. 2009, 54, 1911-1932. [CrossRef]

7. De Vaugelas, J.; Buscail, R. Organic matter distribution in burrows of the thalassinid crustacean Callichirus laurae, Gulf of Aqaba (Red Sea). Hydrobiologia 1990, 207, 269-277. [CrossRef]

8. Maire, O.; Lecroart, P.; Meysman, F.; Rosenberg, R.; Duchêne, J.; Grémare, A. Quantification of sediment reworking rates in bioturbation research: A review. Aquat. Biol. 2008, 2, 219-238. [CrossRef]

9. Thrush, S.F.; Pridmore, R.D.; Hewitt, J.E.; Cummings, V.J. Adult infauna as facilitators of colonization on intertidal sandflats. J. Exp. Mar. Biol. Ecol. 1992, 159, 253-265. [CrossRef]

10. Bouma, T.J.; Olenin, S.; Reise, K.; Ysebaert, T. Ecosystem engineering and biodiversity in coastal sediments: Posing hypotheses. Helgol. Mar. Res. 2009, 63, 95-106. [CrossRef]

11. Widdicombe, S.; Austen, M. Mesocosm investigation into the effects of bioturbation on the diversity and structure of a subtidal macrobenthic community. Mar. Ecol. Prog. Ser. 1999, 189, 181-193. [CrossRef] 
12. Pillay, D.; Branch, G.M.; Forbes, A.T. The influence of bioturbation by the sandprawn Callianassa kraussi on feeding and survival of the bivalve Eumarcia paupercula and the gastropod Nassarius kraussianus. J. Exp. Mar. Biol. Ecol. 2007, 344, 1-9. [CrossRef]

13. Pillay, D.; Williams, C.; Whitfield, A.K. Indirect effects of bioturbation by the burrowing sandprawn Callichirus kraussi on a benthic foraging fish, Liza richardsonii. Mar. Ecol. Prog. Ser. 2012, 453, 151-158. [CrossRef]

14. Pillay, D.; Branch, G.M. Bioengineering effects of burrowing thalassinidean shrimps on marine soft-bottom ecosystems. Oceanogr. Mar. Biol. Annu. Rev. 2011, 49, 137-192. [CrossRef]

15. Dworschak, P.C. Global Diversity in the Thalassinidea (Decapoda). J. Crustacean Biol. 2000, 20, 238-245. [CrossRef]

16. Dworschak, P.C. Global diversity in the Thalassinidea (Decapoda): An update (1998-2004). Nauplius 2005, 13, 57-63.

17. Nickell, L.; Atkinson, R. Functional morphology of burrows and trophic modes of three thalassinidean shrimp species, and a new approach to the classification of thalassinidean burrow morphology. Mar. Ecol. Prog. Ser. 1995, 128, 181-197. [CrossRef]

18. Stamhuis, E.J.; Videler, J.J.; de Wilde, P.A.W.J. Optimal foraging in the thalassinidean shrimp Callianassa subterranea: Improving food quality by grain size selection. J. Exp. Mar. Biol. Ecol. 1998, 228, 197-208. [CrossRef]

19. Dworschak, P.C. Feeding behaviour of Upogebia pusilla and Callianassa tyrrhena (Crustacea, Decapoda, Thalassinidea). Inv. Pesq. 1987, 51, 421-429.

20. Pillay, D. Ecosystem engineering by thalassinidean crustaceans: Response variability, contextual dependencies and perspectives on future research. Diversity 2019, 11, 64. [CrossRef]

21. Griffis, R.B.; Chavez, F.L. Effects of sediment type on burrows of Callianassa californiensis Dana and C. gigas Dana. J. Exp. Mar. Biol. Ecol. 1988, 117, 239-253. [CrossRef]

22. Griffis, R.; Suchanek, T. A model of burrow architecture and trophic modes in thalassinidean shrimp (Decapoda: Thalassinidea). Mar. Ecol. Prog. Ser. 1991, 79, 171-183. [CrossRef]

23. Melo, G.A.S. De Manual de Identificação dos Crustacea Decapoda do Litoral Brasileiro: Anomura, Thalassinidea, Palinuridea, Astacidea; Editora Plêiade: São Paulo, Brazil, 1999; ISBN 978-85-85795-08-5.

24. Candisani, L.C.; Sumida, P.Y.G.; Pires-Vanin, A.M.S. Burrow morphology and mating behaviour of the thalassinidean shrimp Upogebia noronhensis. J. Mar. Biol. Assoc. 2001, 81, 799-803. [CrossRef]

25. Mukai, H. On the changes of benthic communities by a removal experiment of the burrowing bioturbators in the tidal flat of Yamada Bay: Diversity and abundance after one year. Otsuchi Mar. Res. Cent. Rep. 1987, 13, 11-17.

26. Posey, M.H.; Dumbauld, B.R.; Armstrong, D.A. Effects of a burrowing mud shrimp, Upogebia pugettensis (Dana), on abundances of macro-infauna. J. Exp. Mar. Biol. Ecol. 1991, 148, 283-294. [CrossRef]

27. Tamaki, A. Effects of the bioturbating activity of the ghost shrimp Callianassa japonica Ortmann on migration of a mobile polychaete. J. Exp. Mar. Biol. Ecol. 1988, 120, 81-95. [CrossRef]

28. Kato, M.; Itani, G. Commensalism of a bivalve, Peregrinamor ohshimai, with a thalassinidean burrowing shrimp, Upogebia Major. J. Mar. Biol. Assoc. UK 1995, 75, 941-947. [CrossRef]

29. Garcia, K.E.; Embry, S.J.; Grossblat, D.; Holbrook, A.-M.; McLaren, W.M.; Reed, S.K.; Wildley, H.C.; Shuster, S.M. A comparison of two methods for sampling the Gulf of California mud shrimp, Neotrypaea uncinata (Crustacea: Thalassinidea). J. Nat. Hist. 2003, 37, 1847-1854. [CrossRef]

30. Presley, B.J. A simple method for determining calcium carbonate in sediment samples. J. Sediment. Res. 1975, 45, 745-746. [CrossRef]

31. Morisita, M. Iб-Index, a measure of dispersion of individuals. Popul. Ecol. 1962, 4, 1-7. [CrossRef]

32. Smith-Gill, S.J. Cytophysiological basis of disruptive pigmentary patterns in the leopard frog Rana pipiens. II. Wild type and mutant cell-specific patterns. J. Morphol. 1975, 146, 35-54. [CrossRef]

33. Krebs, C.J. Ecological Methodology, 2nd ed.; Benjamin Cummings: Menlo Park, CA, USA, 1998; ISBN 978-0-321-02173-1.

34. Clarke, K.R.; Gorley, R.N.; Somerfield, P.J.; Warwick, R.M. Change in Marine Communities: An Approach to Statistical Analysis and Interpretation, 3rd ed.; Primer-E Ltd.: Plymouth, UK, 2014.

35. Burone, L.; Muniz, P.; Pires-Vanin, A.M.S.; Rodrigues, M. Spatial distribution of organic matter in the surface sediments of Ubatuba Bay (Southeastern-Brazil). An. Acad. Bras. Ciências 2003, 75, 77-80. [CrossRef]

36. Negreiros-Fransozo, M.L.; Fransozo, A.; Pinheiro, M.a.A.; Mantelatto, F.L.M.; Santos, S. Caracterização física e química da Enseada de Fortaleza, Ubatuba, SP. Rev. Bras. Geociências 2017, 21, 114-120. [CrossRef] 
37. Pires-Vanin, A.M.S. A macrofauna bêntica da plataforma continental ao largo de Ubatuba, São Paulo, Brasil. Publicação Espec. Inst. Oceanográfico São Paulo 1993, 10, 137-158.

38. Brasil, A.C.S.; Silva, S.H.G.S. Spatial distribution of polychaeta in a soft-bottom community at Saco Do Ceu, Ilha Grande, Rio de Janeiro, Brazil. Bull. Mar. Sci. 2000, 67, 103-112.

39. Omena, E.P.; Lavrado, H.P.; Paranhos, R.; Silva, T.A. Spatial distribution of intertidal sandy beach polychaeta along an estuarine and morphodynamic gradient in an eutrophic tropical bay. Mar. Pollut. Bull. 2012, 64, 1861-1873. [CrossRef] [PubMed]

40. Arasaki, E.; Muniz, P.; Pires-Vanin, A.M.S. A functional analysis of the benthic macrofauna of the São Sebastião Channel (southeastern Brazil). Mar. Ecol. 2004, 25, 249-263. [CrossRef]

41. Pleijel, F. On feeding of Pholoe minuta (Fabricus, 1780) (Polychaeta:Sigalioinidae). Sarsia 1983, 68, 21-23. [CrossRef]

42. Padovanni, N.; Amaral, A.C.Z. New species of the scale worm genus Pholoe (Polychaeta: Pholoidae) from southeast Brazil. Zootaxa 2013, 3710, 485. [CrossRef]

43. Soares-Gomes, A.; Pires-Vanin, A.M.S. Bivalve mollusk assemblages on São Paulo's northern continental shelf, southeast Brazil. Braz. J. Biol. 2005, 65, 717-727. [CrossRef]

44. Neves, R.A.F.; Echeverria, C.A.; Pessoa, L.A.; Paiva, P.C.; Paranhos, R.; Valentin, J.L. Factors influencing spatial patterns of molluscs in a eutrophic tropical bay. J. Mar. Biol. Assoc. 2013, 93, 577-589. [CrossRef]

45. Nucci, P.R.; Turra, A.; Morgado, E.H. Diversity and distribution of crustaceans from 13 sheltered sandy beaches along São Sebastião Channel, south-eastern Brazil. J. Mar. Biol. Assoc. 2001, 81, 475-484. [CrossRef]

46. Leite, F.P.P.; Turra, A.; Souza, E.C.F. Population biology and distribution of the tanaid Kalliapseudes schubarti Mañé-Garzon, 1949, in an intertidal flat in Southeastern Brazil. Braz. J. Biol. 2003, 63, 469-479. [CrossRef] [PubMed]

47. Omena, E.P.; Amaral, A.C.Z. Sandy beach morphodynamic and the polychaete fauna in southeast Brazil. J. Coast. Res. 2003, 35, 431-439.

48. McDermott, J. The biology of Austinixa gorei (Manning \& Felder, 1989) (Decapoda, Brachyura, Pinnotheridae) symbiotic in the burrows of intertidal ghost shrimp (Decapoda, Thalassinidea, Callianassidae) in Miami, Florida. Crustaceana 2006, 79, 345-361. [CrossRef]

49. Peiró, D.F.; Mantelatto, F.L. Population dynamics of the pea crab Austinixa aidae (Brachyura, Pinnotheridae): A symbiotic of the ghost shrimp Callichirus major (Thalassinidea, Callianassidae) from the southwestern Atlantic. Iheringia Série Zool. 2011, 101, 5-14. [CrossRef]

50. Alves, E.D.S.; Pezzuto, P.R. Population Dynamics of Pinnixa patagoniensis Rathbun, 1918 Brachyura: Pinnotheridae a Symbiotic Crab of Sergio mirim Thalassinidea: Callianassidae in Cassino Beach, Southern Brazil. Mar. Ecol. 1998, 19, 37-51. [CrossRef]

51. Hernáez, P. An Update on Reproduction in Ghost Shrimps (Decapoda: Axiidea) and Mud Lobsters (Decapoda: Gebiidea). In Marine Ecology_Biotic and Abiotic Interactions; Türkoğlu, M., Önal, U., Ismen, A., Eds.; IntechOpen: London, UK, 2018. [CrossRef]

52. Kinoshita, K.; Wada, M.; Kogure, K.; Furota, T. Mud shrimp burrows as dynamic traps and processors of tidal-flat materials. Mar. Ecol. Prog. Ser. 2003, 247, 159-164. [CrossRef]

53. Papaspyrou, S.; Gregersen, T.; Cox, R.P.; Thessalou-Legaki, M.; Kristensen, E. Sediment properties and bacterial community in burrows of the ghost shrimp Pestarella tyrrhena (Decapoda: Thalassinidea). Aquat. Microb. Ecol. 2005, 38, 181-190. [CrossRef]

54. Dobbs, F.; Guckert, J. Callianassa trilobata (Crustacea: Thalassinidea) influences abundance of meiofauna and biomass, composition, and physiologic state of microbial communities within its burrow. Mar. Ecol. Prog. Ser. 1988, 45, 69-79. [CrossRef]

55. Griffen, B.D.; DeWitt, T.H.; Langdon, C. Particle removal rates by the mud shrimp Upogebia pugettensis, its burrow, and a commensal clam: Effects on estuarine phytoplankton abundance. Mar. Ecol. Prog. Ser. 2004, 269, 223-236. [CrossRef]

56. Das, S.; Tseng, L.-C.; Wang, L.; Hwang, J.-S. Burrow characteristics of the mud shrimp Austinogebia edulis, an ecological engineer causing sediment modification of a tidal flat. PLoS ONE 2017, 12, e0187647. [CrossRef] [PubMed]

57. Dworschak, P.C. The Biology of Upogebia pusilla (Petagna) (Decapoda, Thalassinidea) I. The Burrows. Mar. Ecol. 1983, 4, 19-43. [CrossRef] 
58. Bosley, K.M.; Copeman, L.A.; Dumbauld, B.R.; Bosley, K.L. Identification of burrowing shrimp food sources along an estuarine gradient using fatty acid analysis and stable isotope ratios. Estuaries Coasts 2017, 40, 1113-1130. [CrossRef]

59. Kinoshita, K.; Wada, M.; Kogure, K.; Furota, T. Microbial activity and accumulation of organic matter in the burrow of the mud shrimp, Upogebia major (Crustacea: Thalassinidea). Mar. Biol. 2008, 153, 277-283. [CrossRef]

60. Coelho, V.R.; Cooper, R.A.; de Almeida Rodrigues, S. Burrow morphology and behavior of the mud shrimp Upogebia omissa (Decapoda: Thalassinidea: Upogebiidae). Mar. Ecol. Prog. Ser. 2000, 200, 229-240. [CrossRef]

61. MacGinitie, G.E. III.-The natural history of the mud shrimp Upogebia pugettensis (Dana). Ann. Mag. Nat. Hist. 1930, 6, 36-44. [CrossRef]

62. Dworschak, P.C. The pumping rates of the burrowing shrimp Upogebia pusilla (Petagna) (Decapoda:Thalassinidea). J. Exp. Mar. Biol. Ecol. 1981, 52, 25-35. [CrossRef]

63. Ott, J.A. Observations on the biology of Callianassa stebbingi Borrodaille and Upogebia litoralis Risso and their effect upon the sediment. Senckenbergiana Marit. 1976, 8, 61-79.

64. Swinbanks, D.D.; Murray, J.W. Biosedimentological zonation of Boundary Bay tidal flats, Fraser River Delta, British Columbia. Sedimentology 1981, 28, 201-237. [CrossRef]

65. Posey, M.H. Predation on a burrowing shrimp: Distribution and community consequences. J. Exp. Mar. Biol. Ecol. 1986, 103, 143-161. [CrossRef]

66. Dworschak, P.C. The Biology of Upogebia pusilla (Petagna) (Decapoda, Thalassinidea) II. Environments and Zonation. Mar. Ecol. 1987, 8, 337-358. [CrossRef]

67. Hodgson, A.N.; Frssaf, B.R.A.; Cretchley, R. An estimation of the standing stock and population structure of Upogebia africana (Crustacea: Thalassinidae) in the Knysna Estuary. Trans. R. Soc. S. Afr. 2000, 55, 187-196. [CrossRef]

68. Hall-Spencer, J.M.; Atkinson, R.J.A. Upogebia deltaura (Crustacea: Thalassinidea) in Clyde Sea maerl beds, Scotland. J. Mar. Biol. Assoc.UK 1999, 79, 871-880. [CrossRef]

69. Berkenbusch, K.; Rowden, A.A.; Probert, P.K. Temporal and spatial variation in macrofauna community composition imposed by ghost shrimp Callianassa filhoi bioturbation. Mar. Ecol. Prog. Ser. 2000, 192, 249-257. [CrossRef]

70. Angel, A.; Branch, G.M.; Wanless, R.M.; Siebert, T. Causes of rarity and range restriction of an endangered, endemic limpet, Siphonaria compressa. J. Exp. Mar. Biol. Ecol. 2006, 330, 245-260. [CrossRef]

Publisher's Note: MDPI stays neutral with regard to jurisdictional claims in published maps and institutional affiliations.

(C) 2020 by the authors. Licensee MDPI, Basel, Switzerland. This article is an open access article distributed under the terms and conditions of the Creative Commons Attribution (CC BY) license (http://creativecommons.org/licenses/by/4.0/). 